\title{
SlideShare Presentations, Citations, Users and Trends: A Professional Site with Academic and Educational Uses ${ }^{1}$
}

Mike Thelwall, Kayvan Kousha

Statistical Cybermetrics Research Group, University of Wolverhampton, UK.

SlideShare is a free social web site that aims to help users to distribute and find presentations. Owned by Linkedln since 2012, it targets a professional audience but may give value to scholarship through creating a long term record of the content of talks. This article tests this hypothesis by analysing sets of general and scholarly-related SlideShare documents using content and citation analysis and popularity statistics reported on the site. The results suggest that academics, students and teachers are a minority of SlideShare uploaders, especially since 2010 , with most documents not being directly related to scholarship or teaching. About two thirds of uploaded SlideShare documents are presentation slides, with the remainder often being files associated with presentations or video recordings of talks. SlideShare is therefore a presentation-centred site with a predominantly professional user base. Although a minority of the uploaded SlideShare documents are cited by, or cite, academic publications, probably too few articles are cited by SlideShare to consider extracting SlideShare citations for research evaluation. Nevertheless, scholars should consider SlideShare to be a potential source of academic and non-academic information, particularly in library and information science, education and business.

\section{Introduction}

The internet has changed the ways in which scholars and others communicate. Conference speakers may present remotely with videoconferencing software and part of the audience might also be geographically distant using similar technology. In some cases, such as TED Talks, the main audience may watch online afterwards: remote in both time and place (Sugimoto \& Thelwall, 2013). In computer science and engineering, a talk at a major academic conference will typically be underpinned by a refereed full paper in the conference proceedings. Proceedings papers tend to be cited earlier than journal articles (Lisée, Larivière \& Archambault, 2008), confirming the importance of this genre. In many other fields talk attendees and others wishing to access the content of a presentation might only be able to read a short proceedings paper or an abstract and the talk may never generate a fully refereed publication (e.g., Weale, Edwards, Lear, \& Morgan, 2006; Scherer, Dickersin, \& Langenberg, 1994; Petticrew et al., 2008). Nowadays, however, any speaker can put their presentation files online in a personal or professional website or deposit them in an academic repository, such as Figshare. Social web sites that specialise in presentations, including SlideShare, Speaker Deck, projeqt, and authorSTREAM, have the advantage that they include additional functionality, such as online streaming and standardised metadata. A presentation site may also help to attract a new audience directly for the deposited version. Alternatively, a speaker may create their presentation directly within sites such as Prezi. The web therefore contains multiple sources of presentation files, apparently creating a long

\footnotetext{
1 This is a preprint of an article to be published in the Journal of the Association for Information Science and Technology (C) copyright 2016 John Wiley \& Sons, Inc.
} 
term record of a previously transient phenomenon. It is therefore important to assess whether sites like SlideShare are genuinely transforming the scholarly landscape in the sense of including valuable content that makes a long term contribution to academic research. There is also an opportunity to exploit citations in online presentations to assess the non-standard impacts of academic research.

As reviewed below, although a number of studies have investigated the potential to extract impact or interest data from the web about presentations, none have focused on SlideShare. This site was created in October 2006 and was bought by LinkedIn in May 3, 2012 (Seeborg, 2013). SlideShare claims that it included "over 18 million uploads" by January 2016 and its services support the sharing and discovery of knowledge (www.slideshare.net/about, see also: Eveillard, 2013). According to Alexa.com's panel data, SlideShare had become the $156^{\text {th }}$ most popular website by January 2016 (www.alexa.com/siteinfo/slideshare.net), considerably above academic social web sites like Academia.edu (751) and ResearchGate (699). Although SlideShare seems to be the most popular site of its type, there is little evidence about how widely it is used in academia. Less than $6 \%$ of European highly cited researchers have a SlideShare profile in all areas of science except the social sciences (13\%) (Mas-Bleda, Thelwall, Kousha, \& Aguillo, 2014) but Spanish information scientists use the site much more (47\%) (Torres-Salinas, \& Milanés-Guisado, 2014). From the perspective of SlideShare users, even less is known but one study has suggested that in 2012 about $10 \%$ of internet-using advanced practice nurses in the USA used SlideShare (Kung \& Oh, 2014), presumably for viewing health-related presentations. A Scopus cited references search [REF ("*slideshare.net*")] in January 2016 found that some academic publications cite SlideShare presentations (from 2 publications in 2007 to 938 publications from 2015). These numbers are low in comparison to the total number of Scopus articles (e.g., 1.6 million in 2015), although presentations may be viewed much more often than they are cited.

In response to the gap in knowledge about whether SlideShare provides a valuable long term record of talks that are relevant to academia, this study investigates a large sample of SlideShare documents as well as presentations cited by academic research. The secondary goal is to gain insights into the types of indicators that can be created, how likely they are to be useful, in which context they may be most useful, and how the results should be interpreted.

\section{Background}

This section reviews two topics relating to the online sharing of presentations in the social web: scholarly presentations and assessing the impact of online scholarly resources.

\section{Scholarly presentations}

Within academia, except for practice-based arts, an important part of collective scholarship is the creation of a body of publications that records the theories, evidence and analyses that drive forwards or widen knowledge and understanding. This typically takes the form of refereed journal articles, fully refereed conference papers or monographs. Although scholarship could progress solely by exchanging ideas through publications, researchers tend to meet periodically at specialist conferences to present their latest findings to their peers, as well as to consolidate the culture and social organisation of the field (Egri, 1992) and to find jobs (e.g., Oppermann, 1997). 
Scholarly conferences and seminars may have non-researchers attending. In a professional field practitioners may gain insights into new developments (e.g., librarians: Lyons, 2007; Tomaszewski \& MacDonald, 2009) and in the applied sciences, businesses may need access to the state-of-the art discoveries announced, or may themselves publish in conferences. For example, Google and Microsoft employees frequently present at the main information retrieval and web conferences. Academic conferences can follow specific genres or unwritten conventions, even within their spoken parts (Shalom, 1993), and this may alienate a non-academic audience, such as one viewing a presentation online afterwards. Perhaps partly as a result of this, some conferences are organised outside of academia and target non-academics for networking and continuing professional development (e.g., the Fiesole Retreat for library collection development issues), even if some scholars attend or present (Cherrstrom, 2012). Such events probably do not publish proceedings and in the past would have left no permanent record but presenters may now deposit their slides or related reports online for the audience to access afterwards.

Academics can also present outside of conferences to policy makers, a professional audience relevant to their research or a wider public. Presumably these presentations are less likely to be accompanied by a full paper than when presenting to a conference, but presenters may still wish to share their slides. Talks given to a general public are also important to disseminate new ideas or to promote science (Holliman \& Jensen, 2009). The TED Talks conferences are a high profile example of curated presentations aimed at a general public, with a substantial number of presenters originating from academia (Sugimoto, Thelwall, Larivière, Tsou, Mongeon, Macaluso, 2013). These have shown that it is possible to create a huge audience for academic speakers (Sugimoto \& Thelwall, 2013).

Presentations are not just given by academics but also by teachers and instructors in educational and training contexts, by other professionals as part of their jobs and by public speakers for entertainment, life skills and training. Students also routinely give talks as part of their learning (e.g., Gerido \& Curran, 2014) and so any analysis of online presentations should expect to find a wide variety of types and motivations. Nevertheless, presentation file formats are not only used for presentations but may be used as a convenient tool for other purposes, such as project documentation, and so some things that appear to be presentations may be other document genres (Schoeneborn, 2015).

Many presentations are available online as narrated videos in YouTube or other video sharing sites (Kousha, Thelwall, Abdoli, 2012). These have advantages over presentation files because they have fewer technological barriers to access and can easily incorporate sound, such as a recorded lecture (e.g., Johnson, 2015), or may be video recordings of talks.

\section{Impact evidence from non-academic documents}

The research of individual academics, departments or universities is sometimes evaluated with the aid of indicators derived from citations in academic publications (Moed, 2006). The rationale for this is that, in general, research that has had more impact will tend to be cited more often in other academic publications (Moed, 2006; van Raan, 1998) and that these citations may sometimes reflect the contribution of the cited work to the building of scientific knowledge (Merton, 1973). Nevertheless, the non-academic impacts of academic work are valued by society and may not be reflected in citation counts and so there have been calls to identify wider impact indicators for academic outputs. These include altmetrics from the social web (Priem, Taraborelli, Groth, \& Neylon, 2010; Thelwall, \& Kousha, 2015b), 
webometrics from the general web (Thelwall, \& Kousha, 2015a), and patent metrics for commercial value (Narin \& Noma, 1985). Although web indicators are mostly problematic because the unrefereed nature of the web makes them open to manipulation, they may still be useful for self-evaluations (Wouters \& Costas, 2012) and, with appropriate safeguards, to support academics making individual cases for the non-standard impacts of their work (Thelwall, 2014).

Some academics produce outputs other than articles, conference papers and books, that are rarely or never cited, such as educational (e.g., Haran \& Poliakoff, 2011), and scientific outreach videos (Sugimoto \& Thelwall, 2013) or book reviews (Zuccala \& van Leeuwen, 2011). For these, non-standard indicators can sometimes be generated, such as by counting how often they have been viewed online, downloaded, rated or reviewed (Kousha \& Thelwall, 2015). A social psychologist's 2012 Ted Talk "Your body language shapes who you are", for instance, has been viewed over 3 million times but has only received five Scopus citations ${ }^{2}$. This may also be true for SlideShare. A seminar presentation entitled "Quantum Field Theory and the Limits of Knowledge" published on April 20, 2015 in SlideShare has been viewed over 142,500 times but has not been cited in Google Scholar and Scopus indexed publications ${ }^{3}$.

\section{Research Questions}

This article has two separate, but related goals. The first is to assess the extent to which SlideShare is transforming the information value of academic talks by creating a long term and useful record of their contents. This is addressed through a primarily descriptive evaluation of the types of document uploaded, the most popular types of uploader that, and whether the site's usage has evolved over time. This also has the practical importance of giving an overall assessment of SlideShare for academics, librarians and others considering whether it is worth searching or uploading content to the site.

1. Which types of documents are uploaded to SlideShare?

2. How has the usage of SlideShare changed over time?

3. Which kinds of authors generate the most popular SlideShare resources?

The second goal is to evaluate the connections between SlideShare and academic research. In particular, since citation analysis is an important technique to aid the evaluation of research in many different contexts (Moed, 2006), and alternative sources of citations are needed in order to reflect wider types of research impact (Priem, Taraborelli, Groth, \& Neylon, 2010), the potential of SlideShare to form a new source of citations should be assessed. For example, citations professional presentations may tend to cite articles that are useful for practitioners and educational presentations may cite publications that are easy for learners to understand. In the opposite knowledge flow direction, SlideShare may be a source of evidence for academic research if it contains useful information or ideas. If true, then researchers and librarians may need to add SlideShare to their literature search strategies.

4. Could citations from SlideShare documents to academic articles be a useful source of impact evidence?

5. Which types of SlideShare documents are valuable in academic research?

\footnotetext{
${ }^{2}$ https://www.ted.com/talks/amy_cuddy_your_body_language_shapes_who_you_are

${ }^{3}$ http://www.slideshare.net/seanmcarroll/quantum-field-theory-and-the-limits-of-knowledge
} 


\section{Data and Methods}

Three SlideShare samples were created: general SlideShare documents uploaded during specific dates (2006-2015); SlideShare documents citing academic articles; and SlideShare documents cited by academic articles. The first was used to address the general research questions $(R Q 1,2,3)$ and the other two were used to answer the citation-specific questions $(\mathrm{RQ} 4,5)$.

\section{Data set 1: General SlideShare documents}

SlideShare does not provide a complete list of documents uploaded by users and so an alternative method was used to generate a large sample. For the general SlideShare documents, Bing queries were constructed to search for documents published on every day from the start of SlideShare, October 1, 2006 (it formally launched on October 4, 2006 but some documents had earlier dates) until September 17, 2015. These queries take advantage of every document containing the upload date in a standard format. Submitting a separate query for each day exploits Bing to harvest a large list of documents, despite Bing's limit of less than 1000 results per query (Thelwall \& Sud, 2012). The queries were constructed to capture SlideShare pages based upon exact matches of specific dates, in the standard SlideShare format, in combination the site:slideshare.net command to restrict the results to SlideShare internet domain.

"Published on Oct 01, 2006" site:slideshare.net

"Published on Sep 10, 2015" site:slideshare.net

The searches were conducted from the UK using the Bing API through Webometric Analyst with the default search settings ("en-GB" search market and "moderate" adult content filtering; personalisation should not apply to these results). The queries returned an average of 536 matching SlideShare URLs, with the most URLs returned by any single query being 930. Although 930 is below the theoretical maximum of 1000 URLs per query, Bing seems to truncate its search results sometimes at lower values. Thus, it seems likely that some additional bias was introduced by the queries for which only the top ranked pages were returned rather than a complete set. This bias would presumably be towards more popular pages, such as those that were the target of hyperlinks or that had been frequently visited by Bing users. Manual checks of the URLs suggested that the API did not ever return false matches for the queries. The following file contains an example of a complete list of URLS returned by the Bing API for one of the queries, all of which seem to be correct: https://dx.doi.org/10.6084/m9.figshare.3796206.

From the resulting list of SlideShare URLs, a random sample of 5,000 was taken from each year between 2006 and 2015, with equal numbers from each available month. The list of URLs is available here https://dx.doi.org/10.6084/m9.figshare.3796206. These were then downloaded using the free web crawler SocSciBot.

The number of comments, likes, visits, and downloads in the crawled pages was extracted and processed using a new function added to the free software Webometric Analyst (Services menu, SlideShare menu item, see http://lexiurl.wlv.ac.uk/). These are all presented in a standard format and so could be reliably extracted from the downloaded pages. The documents contain a job description field for the uploader that was also automatically extracted and processed. Members were regarded as lecturers if an automatic text match of their job description field (after their name in the web page) found one of the following text strings (including partial matches, so that lectur includes lecturer): lectur, professor, profesor, academic, researcher, docent. They were regarded as a student if their 
job description field contained student or studient, or a teacher if their job description field contained teacher. This is an approximation because there are many other terms to describe these roles in different languages (e.g., professeur means teacher in French), some may not describe their job, or may describe a previous job (e.g., "former teacher"), and some may use non-standard language (e.g., "professional confuser"). Moreover, under half (19,564 or $39 \%)$ of the uploaders declared an occupation. An investigation of a random sample of 100 suggested that the keywords were reasonably accurate but missed some matches. Two job descriptions reported just "Working" and a third job description of "Working" was associated with a presentation about the attractions of a university department, suggesting that the author was a professor there. Another was an "ICT Educator" at a German professional training organisation, one "Investigador" at "USC" was found to be employed at the University of Santiago de Compostela. Assuming that there were 3 additional lecturers per 100 uploaders, this suggests that the number of lecturers might be underestimated by about 1500 . Moreover, since only $39 \%$ of people reported an occupation, all figures would need to be multiplied by 2.5 to correct for those not reporting an occupation.

A few (137) of the pages had been deleted by the time of the crawl, including four from an apparently phantom Spanish parallel site es.slidehare.net that does not exist, resulting in a final total of 49,863 general documents.

\section{Data set 2: SlideShare documents citing Scopus articles}

The SlideShare documents citing Scopus articles were derived from an initial set of 347,876 Scopus articles in English indexed in the period 2005 to 2013 across 16 subject areas in science (Astronomy and Astrophysics, Biochemistry Computer Science, Environment Science), medical sciences (General Medicine, Surgery, and Nursing), social sciences (Business, Management and Accounting, Education, Political Science, Psychology and Library and Information Science) and the arts and humanities (History, Law, Literature, and Philosophy). Scopus was used for its greater coverage of the academic literature than the main alternative, the Web of Science (e.g., López-Illescas, de Moya-Anegón, \& Moed, 2008), although Scopus may include a lower proportion of non-English academic journals (de Moya-Anegón, et al., 2007). Overall, however, the choice of database probably does not affect the results much (Archambault, Campbell, Gingras, \& Larivière, 2009). The advanced Scopus search command 'subjmain' was applied with labelled numeric codes for each discipline (e.g., subjmain(2900) for Nursing) to restrict the Scopus searches to each specific field. These fields were selected to include a wide range of different areas of scholarship. The years 2005-2013 were chosen to cover a long time window, starting a year before SlideShare was launched and finishing in 2013 to give academic articles enough time to attract citations.

For each subject area and year, a random sample of 2,500 articles was taken from the Scopus data, excluding records without authors or with less than three words in their titles (e.g., "Old News" or "Performance Metrics") to avoid retrieving many false matches during the subsequent search process. Some short titles were apparently incorrectly indexed as articles in Scopus (e.g., "Introduction", "Editorial", "Opening Address", "Conference Summary"). Predefined queries were automatically generated from the Scopus data with the first author's last name, the first (up to) ten terms of the article title as a phrase search, the publication year, and the site:slideshare.net command to restrict the results to SlideShare.net (see the examples below). The queries were automatically 
submitted to the Bing Application Programming Interface (API) by the Webometric Analyst software.

- Bernard "A meta-analysis of three types of interaction treatments in distance" 2009 site:slideshare.net

- Tondeur "Towards a typology of computer use in primary education" 2007 site:slideshare.net

This generated a systematic sample of SlideShare documents citing Scopus articles published in the given subjects and years.

\section{Data set 3: SlideShare documents cited by Scopus articles}

The Scopus query REF ("*www.slideshare.net*") was used in January 2016 to identify articles in Scopus that cited at least one academic publication (this gives more results than the Scopus WEBSITE command). Scopus article records (including cited references) were then downloaded and a programme was used to extract the SlideShare URLs from the 3,718 Scopus cited references in each year. All URLs were then combined, after discarding citations to the website itself or other general parts of the site (www.slideshare.net/about), in order to count how often each SlideShare document had been cited in Scopus. For instance, an academic presentation (Vesiculo-Bullous Diseases, www.slideshare.net/UDDent/vesiculo-bullous-d1) was cited by an article (Acute necrotising ulcerative gingivitis in an immunocompromised young adult) published in BMJ Case Reports in 2015. Some Scopus articles cited multiple SlideShare documents and hence there are more Scopus citations to SlideShare documents $(4,436)$ than citing Scopus documents $(3,718)$.

\section{Analysis 1: Types of document uploaded to SlideShare}

To identify the typical types of document uploaded to SlideShare, a random sample of 100 URLs from data set 1 was manually checked for each of three separate years. The three years were selected to reveal any differences over time in the site. The categorisation covered four general features (author, document type, and purpose) and the academic subject. Each category was constructed after visiting a sample of pages to check for general themes. The subject category initially used Scopus broad subject categories but it was difficult to get a reasonable degree of inter-coder consistency. For example, a "digital revolution for ebusiness management" presentation fits within both computing and business. The subject categories were broadened to a few common areas, but retaining the narrow topics of business and computer science due to their frequency in the data. The instructions and URLs given to the coders are available online (https://dx.doi.org/10.6084/m9.figshare.3796206).

The categorisation was conducted by two independent coders visiting each page. Cohen's kappa (Cohen, 1960) inter-rater agreement values were calculated for each facet. This assesses agreement rates in a way that compensates for chance agreement and gives scores between -1 (perfect disagreement) and 1 (perfect agreement) with values greater than 0 indicating a level of agreement above chance. The agreement rates for each facet were at least moderate (Table 1), using the standard interpretations (Landis \& Koch, 1977), validating the results.

Table 1. Cohen's kappa agreement rate indicators for 100 randomly selected SlideShare documents from each year collected ( $n=300$ altogether). 


\begin{tabular}{|l|l|l|}
\hline Facet & Kappa & Interpretation \\
\hline Author type & 0.698 & Substantial agreement \\
\hline Document type & 0.920 & Almost perfect agreement \\
\hline Research or teaching orientation & 0.552 & Moderate agreement \\
\hline Subject & 0.568 & Moderate agreement \\
\hline
\end{tabular}

\section{Analysis 2: Changes over time}

An overview of trends in popularity can be obtained by comparing the popularity statistics for SlideShare documents published in different years. The statistics extracted from the general SlideShare documents (data set 1 ) were split by document publication year in order to identify trends in time. Since popularity data is typically highly skewed, geometric means were calculated rather than arithmetic means. For the geometric mean, one was added to all the data before calculation as a standard method to allow calculations in the presence of zeros. The geometric mean is therefore the arithmetic mean of the natural logarithm of each metric score plus one, with this arithmetic mean transformed by being raised to the power $e$ and then 1 subtracted ${ }^{4}$. Confidence intervals were calculated for the geometric means using the standard normal distribution formula applied to the logarithm of the data. Although the data could be reported by month rather than by year, the advantages of reporting by year are that narrow confidence intervals can be calculated and that monthly figures would be affected by unrelated factors, such as academic calendars around the world, and unequal month lengths.

To give an additional academic perspective, the academic-related occupations of the uploaders were also reported by year and the number of citations to SlideShare from Scopus articles (data set 3 ) was reported for each article publication year.

\section{Analysis 3: Author popularity}

To address the second research question, uploader types needed to be compared with popularity statistics for their uploaded documents. Since the proportion of uploaders in each category varied substantially over time, in order to identify differences between them, only uploaders from a single year were compared. The year 2013 was chosen for relatively large category sizes for the three categories of interest together with sufficient time to attract substantial numbers for the metrics. Averages were calculated for the popularity metrics available on each site (views, downloads, likes, comments) using the geometric mean (as above) rather than the arithmetic mean because all metrics were highly skewed.

\section{Analysis 4: Impact value of citations from SlideShare documents}

In order to assess whether counts of citations from SlideShare documents to academic articles reflect a similar type of impact to counts of citations from Scopus to academic articles, Spearman correlations were calculated between Scopus and SlideShare citation counts for each field analysed (data set 2; also using the Scopus-indexed citation counts for each Scopus document). Pearson correlations were not used because citation data is highly skewed and hence inferences based upon Pearson values would be unsound. The purpose of calculating this correlation is that Scopus citations are known to broadly reflect academic impact and academic judgement (e.g., HEFCE, 2015), at least in large scale analyses, and so a positive correlation with citations from SlideShare documents suggests, without proving,

\footnotetext{
${ }^{4}$ Worked examples: http://altmetrics.blogspot.co.uk/2015/10/geometric-means-for-citation-counts-and.html
} 
that citations from SlideShare at least partially reflect a type of academic impact (Sud \& Thelwall, 2014).

\section{Analysis 5: Types of SlideShare documents cited by Scopus articles}

In order to assess the format, purpose (research or teaching orientation) and creators of SlideShare files cited by Scopus articles, a random sample of 30 SlideShare URL citations from Scopus publications from data set 3 was checked from each of the 16 selected Scopus subjects areas $(30 \times 16=480)$. The SlideShare documents were coded for document format, research or teaching orientation, and author or creator type. Only documents of type presentation were analysed for the remaining two categories in order to focus on the characteristic SlideShare genre. The categorisation was again conducted by two independent coders and Cohen's kappa inter-coder agreement values were found to be 0.986 (format), 0.546 (research or teaching orientation), 0.441 (author or creator type), all of which are at least moderate (Landis \& Koch, 1977).

\section{Results}

\section{RQ1: Types of document uploaded to SlideShare}

The classification of 100 randomly selected SlideShare files from each of three years gives insights into the typical uses and users of the site. The proportion of presentation slides fell between 2006 and 2010 from close to $100 \%$ to about 68\%, suggesting that the site was originally intended for, or only allowed, standard presentation format documents but subsequently incorporated a substantial minority of other file formats (Figure 1). These were primarily papers (e.g., "Hong Kong is always an ideal place for investment despite the unfounded European Commission tax haven blacklist" ${ }^{5}$ ) and were often in PDF format. There were also some videos (e.g., "John Taft: The Path to Enlightened Finance" ${ }^{6}$ ), animated presentations with a voiceover that were classified as videos (e.g., "Almighty God | Almighty God's Utterance 'Corrupt Man Cannot Represent God'"17) and sets of images without any text (e.g., "Express Education \& Career Expo 2015 Fashion Show" ${ }^{8}$ ) associated with presentations. A similar pattern is evident for uploader occupations: academics and teachers initially formed about $16 \%$ of uploaders but this proportion halved to $8-10 \%$ from 2006 to 2010 (Figure 2).

\footnotetext{
5 http://www.slideshare.net/clebourgeois/hong-kong-is-always-an-ideal-place-for-investment-despite-theunfounded-european-commission-tax-haven-blacklist

${ }_{7}^{6}$ http://www.slideshare.net/LinkedInPulse/weekend-essay-john-taft

http://www.slideshare.net/AlmightyGodisReturnedJesus/025-corrupt-man-cannot-represent-god-thechurch-of-almighty-god

${ }^{8}$ http://www.slideshare.net/kamranmayo/express-education-career-expo-2015-fashion-show
} 


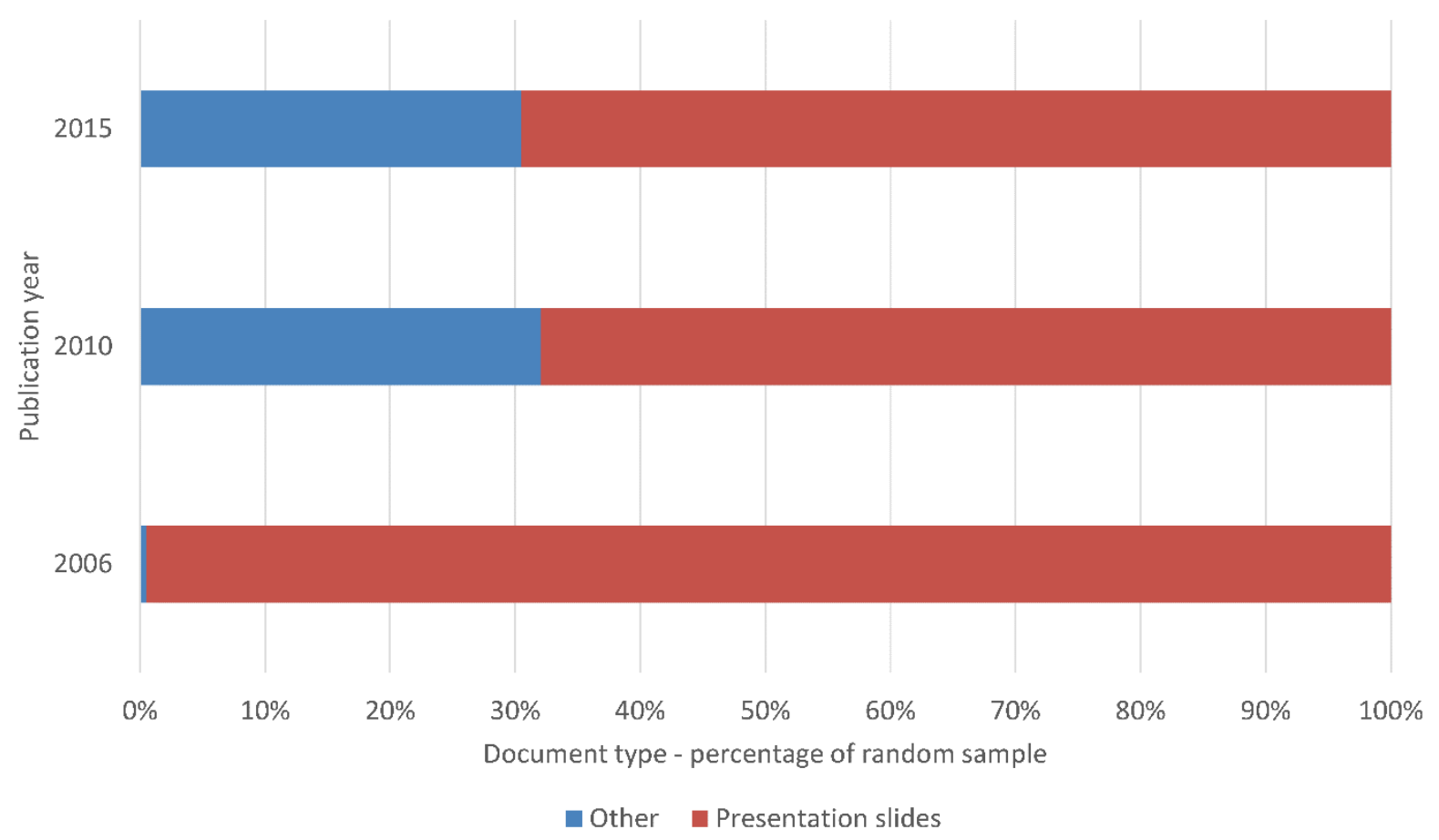

Figure 1. Document types for 100 randomly selected SlideShare files in each of three years (from data set 1 ).

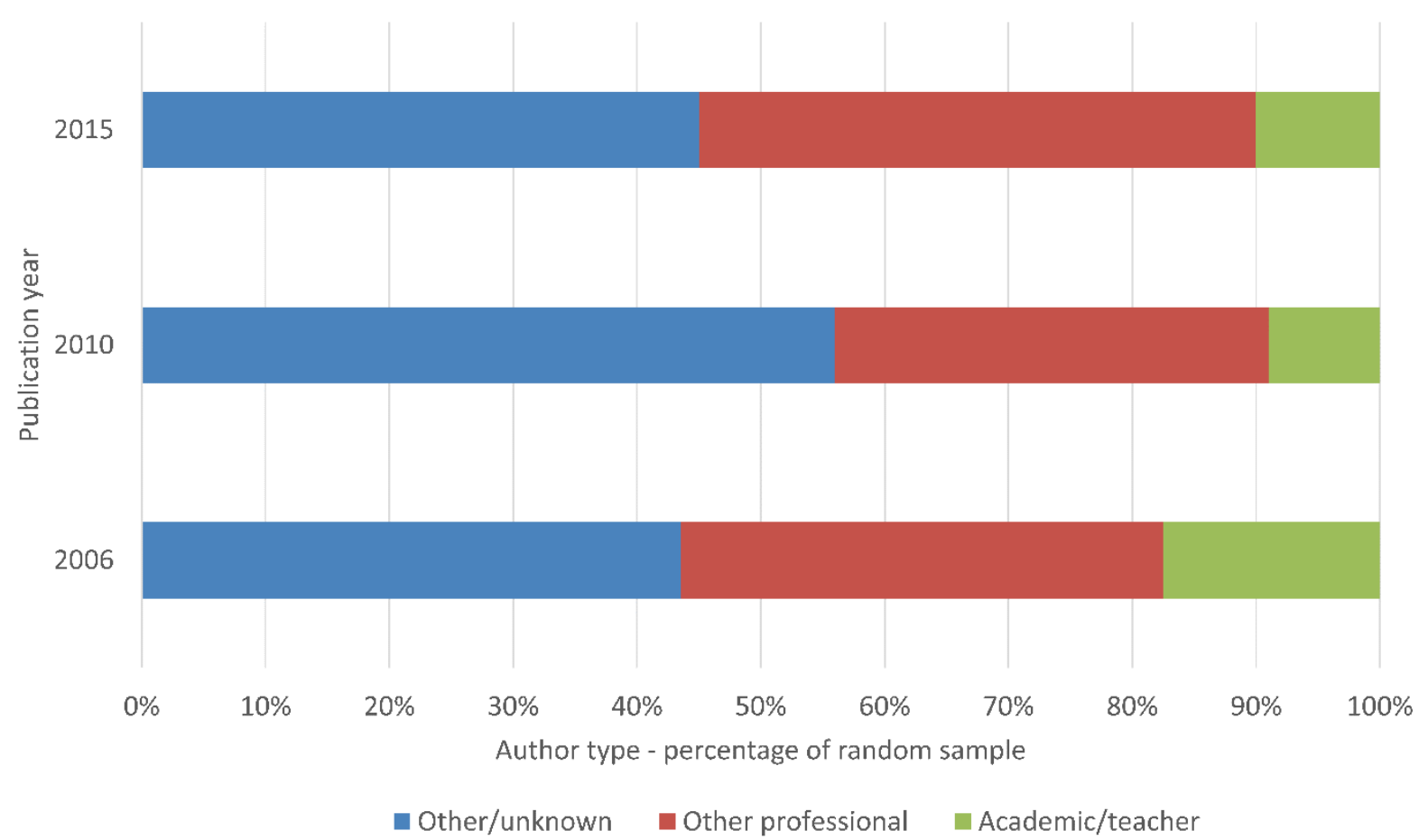

Figure 2. A categorisation of author types for 100 randomly selected SlideShare files in each of three years (from data set 1 ).

Only a minority of SlideShare documents in all years conformed to a recognised academic or educational genre (Figure 3), and this proportion decreased over time to about a third in 2015. This suggests that SlideShare is increasingly dominated by non-educational users. Despite this, a majority of the documents could be broadly classified within an academic 
field in all years (Figure 4), although the proportion fell substantially after 2006. This suggests that many non-academic, non-educational documents still had academic-related content. For example, they may be from highly educated professionals or an interested lay public.

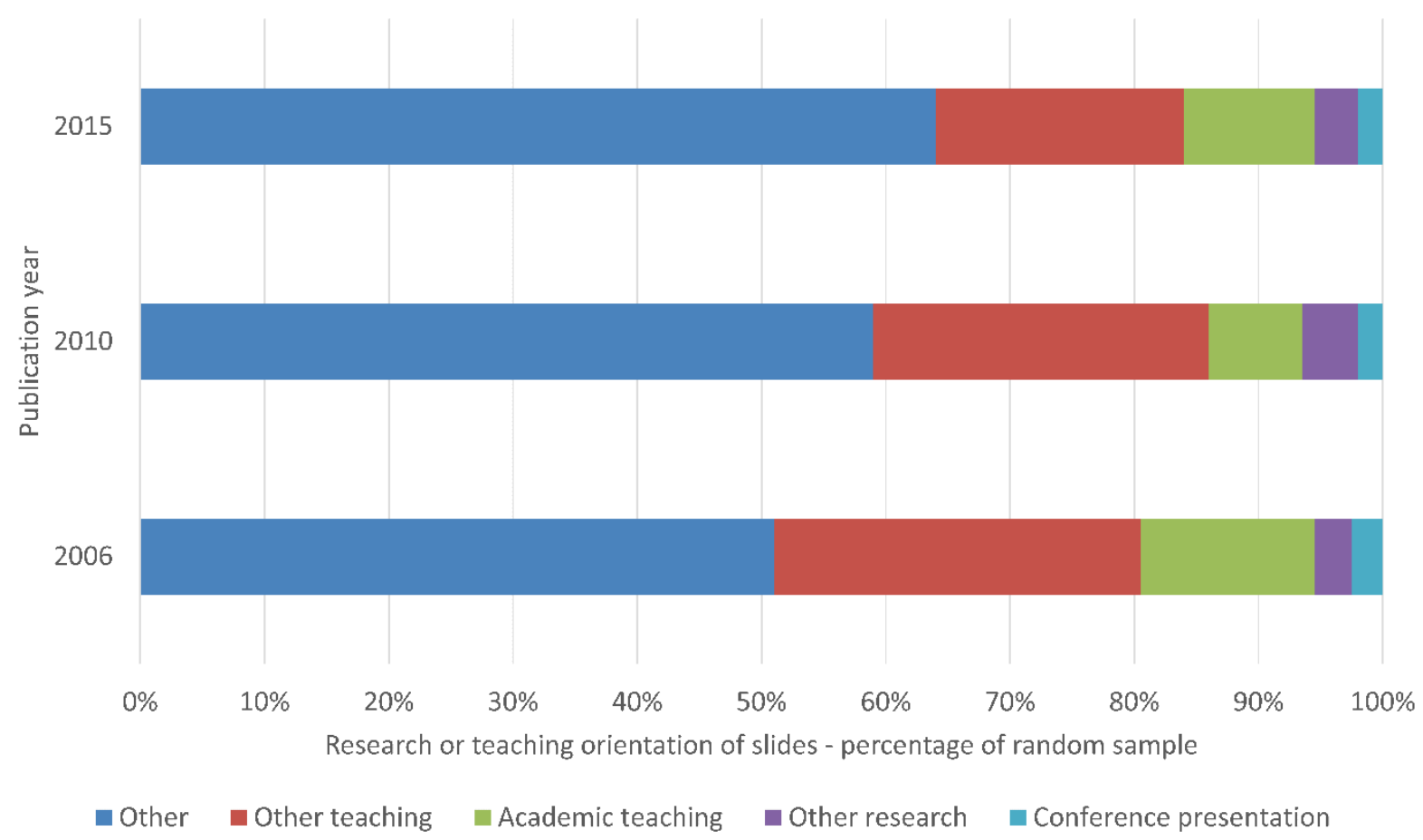

Figure 3. A categorisation of apparent research, teaching or other purposes for 100 randomly selected SlideShare files in each of three years (from data set 1 ).

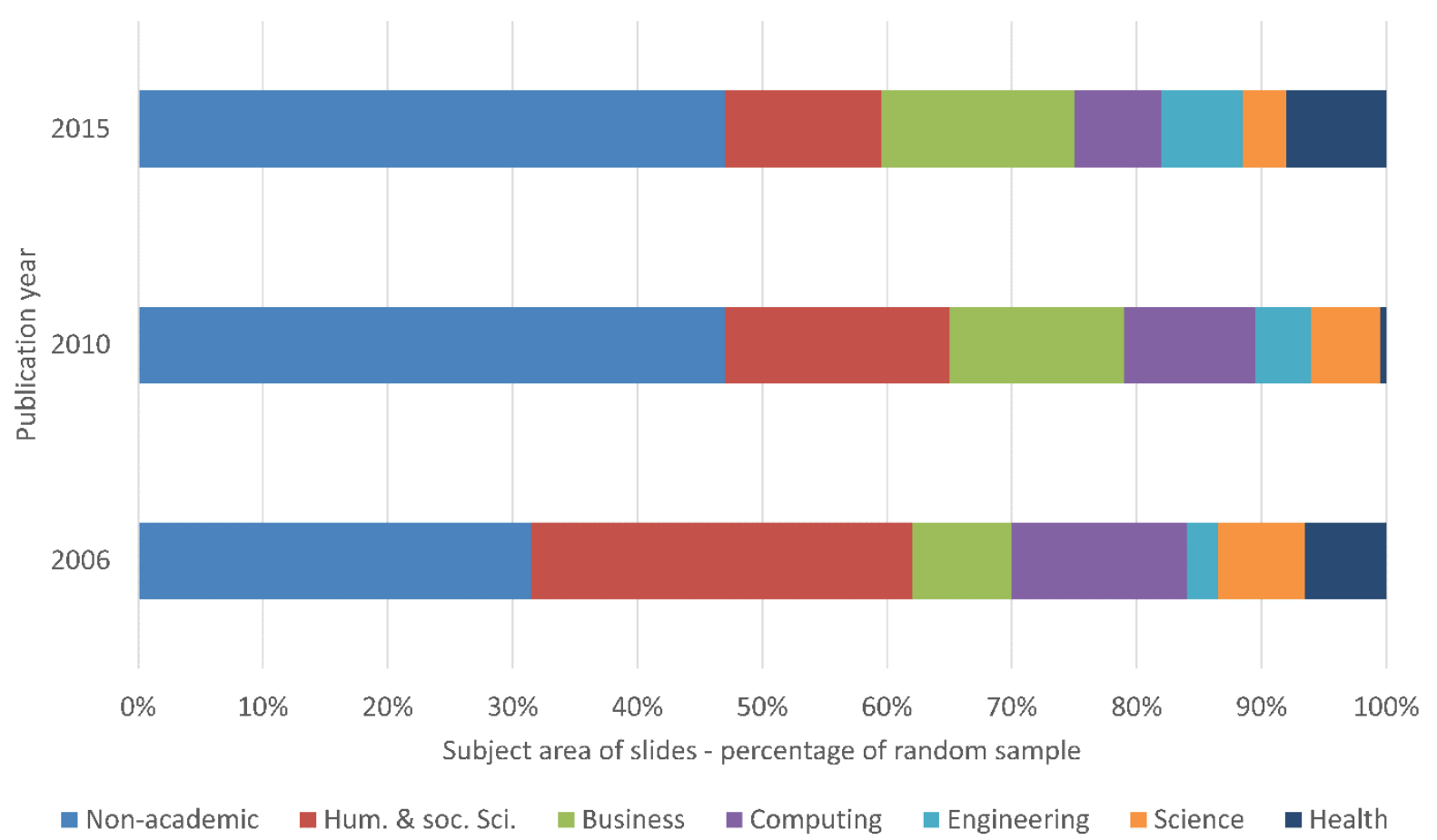

Figure 4. A categorisation of the broad academic subjects of 100 randomly selected SlideShare files in each of three years (from data set 1 ). 


\section{RQ2: Changes in SlideShare usage over time}

Unsurprisingly, older documents tended to have more comments, views, downloads and likes than did newer ones (Figures 1-4), presumably because they had longer to attract them. Documents from the first year and to some extent also from the second year tended to attract relatively few downloads, however. This is probably because downloading only became possible in April 2007 (Jon, 2007) and it seems likely that documents typically attract a substantial proportion of downloads shortly after being posted - perhaps including a few trial downloads from the author. The number of likes per document increased in 2013, which may be due to a site redesign that made it easier to register likes (Loof, 2013).

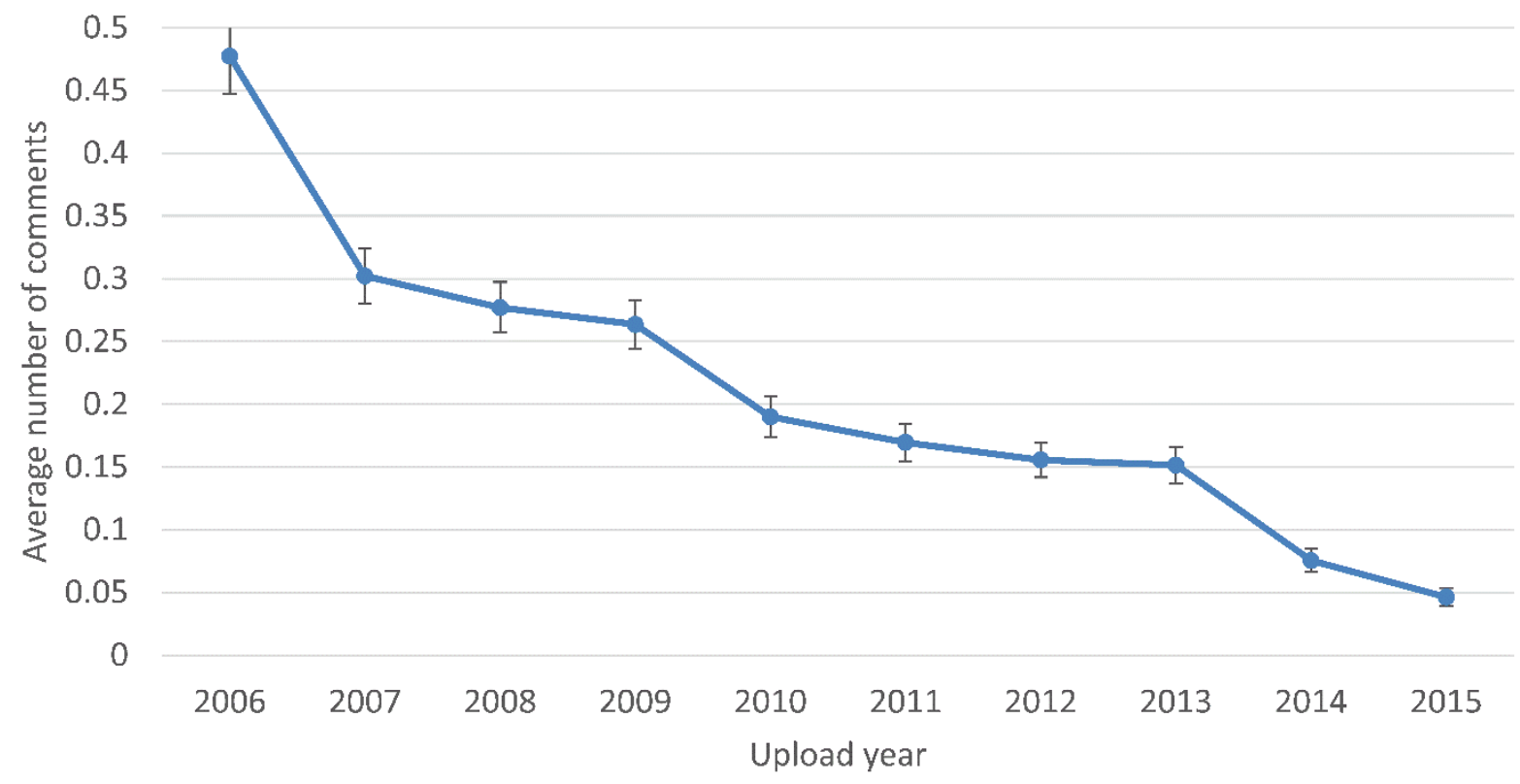

Figure 5. Average (geometric mean) numbers of comments per document by upload year. Error bars show 95\% confidence intervals (data set 1: general documents, $n=49,863$ ).

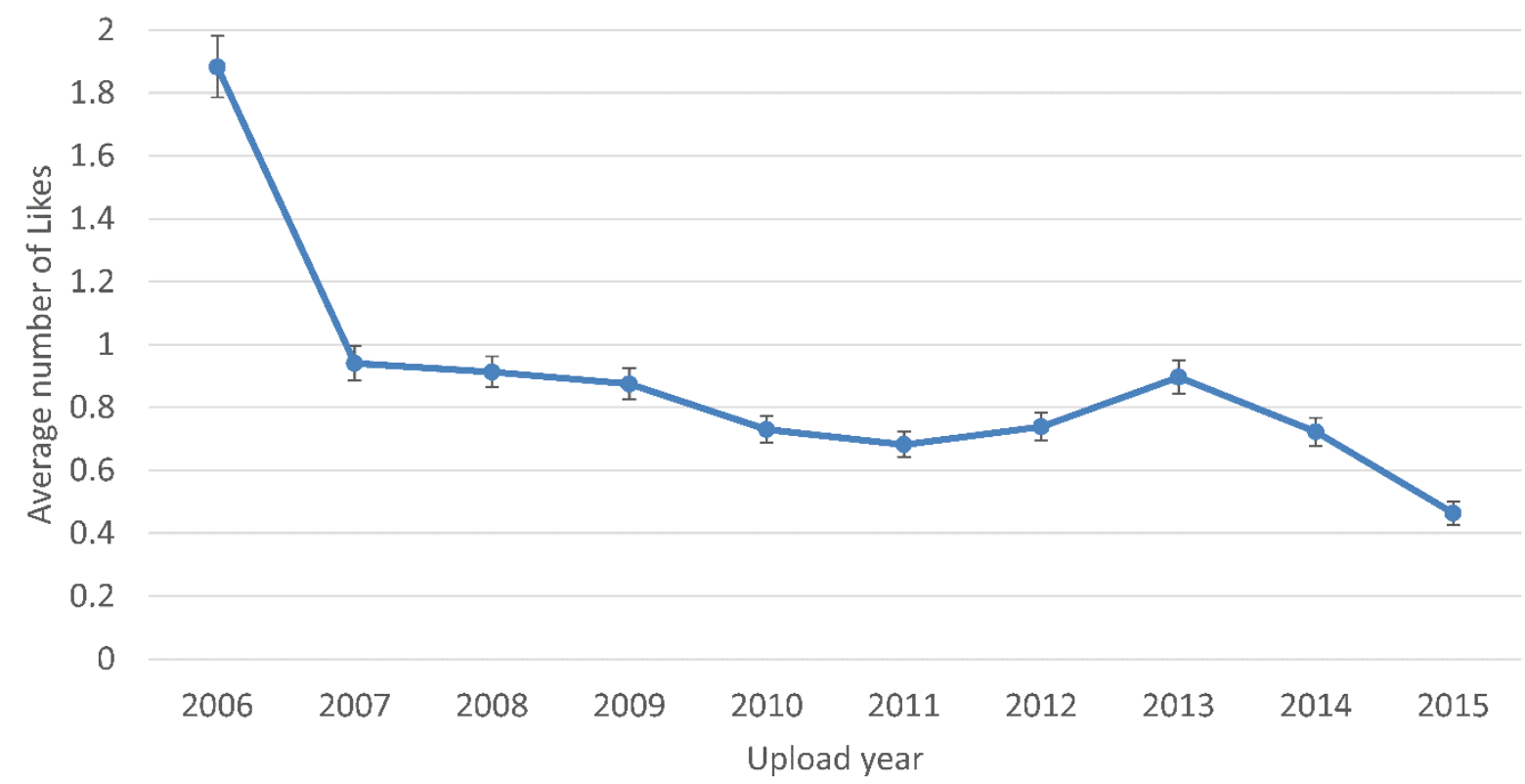

Figure 6. Average (geometric mean) numbers of likes per document by upload year. Error bars show $95 \%$ confidence intervals (data set 1 : general documents, $n=49,863$ ). 


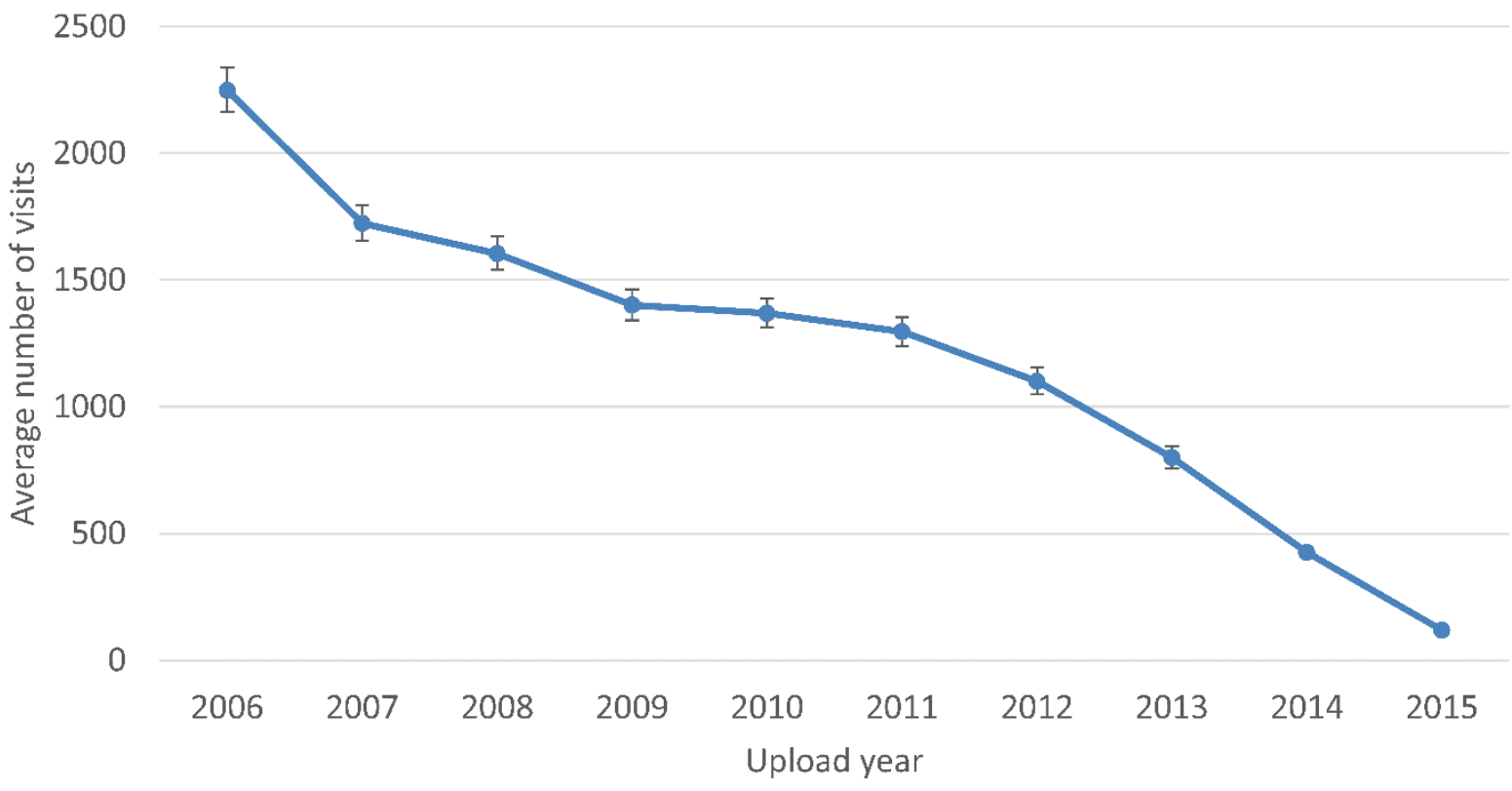

Figure 7. Average (geometric mean) numbers of visits per document by upload year. Error bars show 95\% confidence intervals (data set 1: general SlideShare documents, $n=49,863$ ).

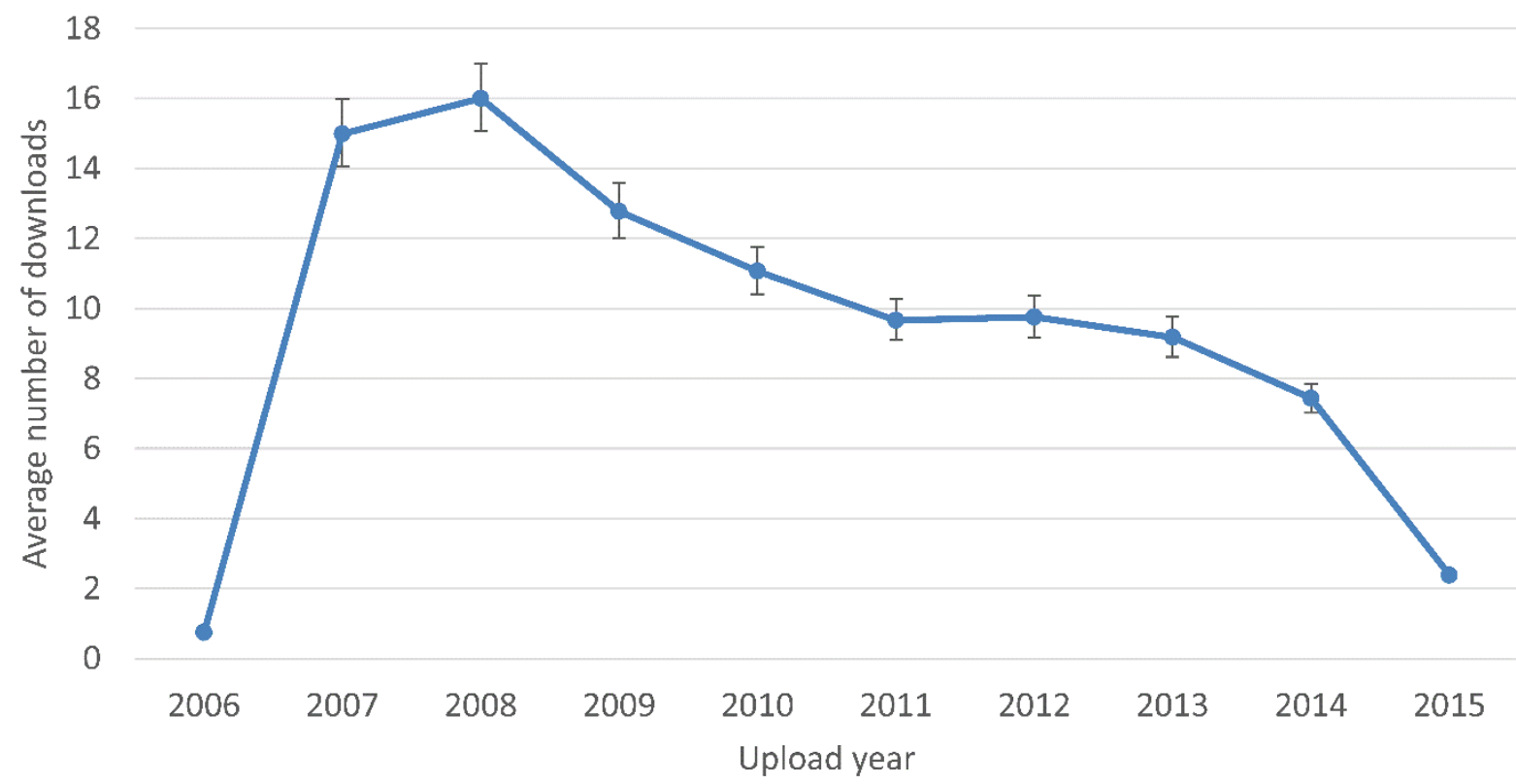

Figure 8. Average (geometric mean) numbers of downloads per document by upload year. Error bars show 95\% confidence intervals (data set 1: general SlideShare documents, $n=49,863)$.

The proportion of users declaring themselves to be affiliated with education has decreased over time quite substantially, suggesting that SlideShare is increasingly reaching an audience outside of education (Figure 9). Given the ongoing rapid increase in SlideShare uptake, the absolute numbers of all of these groups are probably increasing rapidly, even for lecturers, but they are less important overall. As discussed in the methods section, these figures are underestimates and probably reflect approximately a third of the people in each category. 


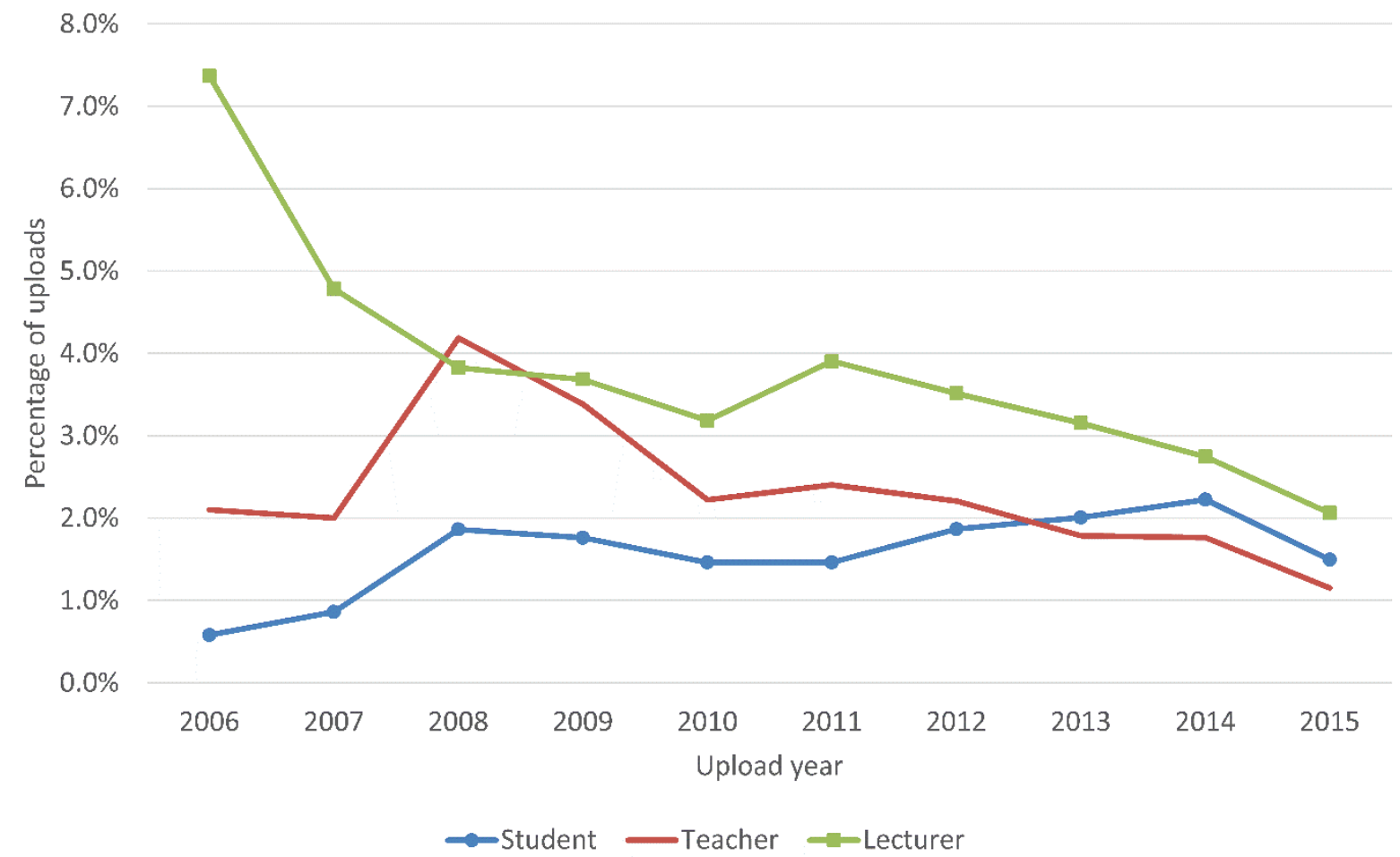

Figure 9. Proportion of uploaders declared as lecturers, teachers or students by year (data set 1: general SlideShare documents, $n=49,863)$.

\section{RQ3: SlideShare document popularity by uploader type}

Some types of SlideShare user uploaded more popular documents than did other types (Table 2). Although the average numbers of comments and likes per document did not vary much between categories, they were lower for the 'Other' category (presumably mainly outside of academia). Student documents were downloaded and visited more often than documents from lectures and teachers (although the page visits difference between teachers and students is small). This may be through classmates showing interest in their work or by different members of a team accessing their group documents, although this is only speculation. Alternatively, the most popular slides from lecturers and teachers may be placed within institutional learning environments, or students may access other students' presentations in order to copy or imitate them for class assignments. The clearest overall result is that academic-related documents were substantially more popular than nonacademic documents across all metrics. Presumably, those in education have access to a natural audience for their work in the form of their peers, students or pupils. This may also be true for some types of users outside of academia, such as touring speakers. 
Table 2. Geometric mean statistics (and 95\% confidence intervals) by job category for slides uploaded in 2013 (data set 1: general SlideShare documents).

\begin{tabular}{|l|l|l|l|l|}
\hline Metric & Lecturers & Teachers & Students & Other \\
\hline \multirow{4}{*}{ Comments } & 0.30 & 0.22 & 0.33 & 0.14 \\
\hline & $(0.19 ; 0.42)$ & $(0.10 ; 0.37)$ & $(0.16 ; 0.52)$ & $(0.13 ; 0.16)$ \\
\hline & 1.64 & 1.49 & 2.30 & 0.84 \\
Likes & $(1.19 ; 2.17)$ & $(1.00 ; 2.11)$ & $(1.62 ; 3.17)$ & $(0.79 ; 0.90)$ \\
\hline & 20.4 & 17.4 & 60.9 & 8.4 \\
\hline & $(14.0 ; 29.7)$ & $(10.4 ; 28.7)$ & $(38.6 ; 95.7)$ & $(7.9 ; 9.0)$ \\
\hline & 1,532 & 1,707 & 2,339 & 753 \\
\hline Page visits & $(1,158 ; 2,025)$ & $(1,166 ; 2,499)$ & $(1,660 ; 3,295)$ & $(713 ; 797)$ \\
\hline
\end{tabular}

RQ4: Citations to articles from Scopus against citations from articles from SlideShare

A very small percentage of Scopus articles are cited by SlideShare documents (Table 3) as retrieved by the Bing API - with a total of $5.4 \%$ of articles being cited by SlideShare. In contrast, $74.5 \%$ of the same set of articles received at least one citation from another Scopus document (varying from Literature [38\%] to General Medicine [90\%]). The percentage of articles with at least one citation varies substantially from $0.8 \%$ (Literature) to 9.9\% (Education), 11\% (Business, Management and Accounting), and 13.8\% (Library and Information Science). This suggests that there are substantial disciplinary differences in the use of SlideShare. The variations could be partly due to differing citation practices, such as the use of short citation formats (e.g., abbreviated journal names, omitting titles from references) in science and medicine, differing average reference list lengths, and mentioning scholars rather than their individual works in the humanities. 
Table 3. SlideShare documents citing Scopus articles published during 2005-2013 (data set 2).

\begin{tabular}{|c|c|c|}
\hline Scopus category & Articles & $\begin{array}{l}\text { SlideShare documents citing } \\
\text { Scopus articles: } \\
\text { No. (\% of articles with at } \\
\text { least one citation from } \\
\text { SlideShare) max. citations for } \\
\text { a single article }\end{array}$ \\
\hline Astronomy and Astrophysics & 22,410 & $486(1.6 \%) 14$ \\
\hline Biochemistry, Genetics \& Molecular Biology & 22,234 & $948(3.1 \%) 32$ \\
\hline Computer Science & 22,363 & $2,369(5.2 \%) 107$ \\
\hline Environmental Science & 22,430 & $1,570(3.3 \%) 91$ \\
\hline General Medicine & 21,938 & $2,241(6.4 \%) 33$ \\
\hline Nursing & 21,525 & $2,148(7.3 \%) 17$ \\
\hline Surgery & 22,090 & $1,096(3.8 \%) 19$ \\
\hline Business, Management and Accounting & 21,790 & $4,872(11 \%) 131$ \\
\hline Education & 22,128 & $3,787(9.9 \%) 65$ \\
\hline Library and Information Science & 22,394 & $6,272(13.8 \%) 97$ \\
\hline Political Science \& International Relations & 20,984 & $1,736(5.2 \%) 29$ \\
\hline Psychology & 22,228 & $1,917(5.2 \%) 28$ \\
\hline History & 21,838 & $396(1.4 \%) 12$ \\
\hline Law & 21,111 & $1,545(5.2 \%) 29$ \\
\hline Literature & 20,218 & $238(0.8 \%) 13$ \\
\hline Philosophy & 20,195 & $512(1.9 \%) 27$ \\
\hline All fields & 347,876 & $32,133(5.4 \%) 131$ \\
\hline
\end{tabular}

Table 4 shows that the citations have increased substantially over time, but may have stopped increasing in 2014.

Table 4. Citations to SlideShare documents in the URLs of reference lists in Scopus-indexed publications, by year of publication of the article (data set 3 , January 3,2016 ).

\begin{tabular}{|l|l|}
\hline Publication year & Number of citations to SlideShare documents \\
\hline 2015 & 938 \\
\hline 2014 & 1,073 \\
\hline 2013 & 897 \\
\hline 2012 & 683 \\
\hline 2011 & 445 \\
\hline 2010 & 264 \\
\hline 2009 & 108 \\
\hline 2008 & 26 \\
\hline 2007 & 2 \\
\hline Total citations & $\mathbf{4 , 4 3 6}$ \\
\hline
\end{tabular}

*Excluding general citations in the reference lists such as slideshare.net, slideshare.net /about or slideshare.net /tour 
The Spearman correlations between the number of Scopus citations and the number of SlideShare citations to Scopus articles are positive and statistically significant in each year examined (Table 5). This supports, but does not prove, the hypothesis that citations from SlideShare documents tend to reflect a type of academic-related impact and are therefore worth assessing, in principle. The low correlations, varying from 0.040 to 0.379 are probably mainly due to the large number of articles without any SlideShare citations (i.e., zeros in the data) rather than the underlying strength of the relationship. Thus, the correlations tend to be strongest for subjects and years with the most data (articles from 2005 in Business, Education, and Library and Information Science). 
Table 5. SlideShare documents citing Scopus articles by subject and year (data set 2) (Spearman correlation between Scopus citations and SlideShare mentions of Scopus articles).

\begin{tabular}{|c|c|c|c|c|c|c|c|c|c|}
\hline Scopus Field* & 2005 & 2006 & 2007 & 2008 & 2009 & 2010 & 2011 & 2012 & 2013 \\
\hline $\begin{array}{l}\text { Astronomy and } \\
\text { Astrophysics }\end{array}$ & $\begin{array}{l}1.3 \% \\
(.252)\end{array}$ & $\begin{array}{l}2 \% \\
(.124)\end{array}$ & $\begin{array}{l}1.5 \% \\
(.121)\end{array}$ & $\begin{array}{l}1 \% \\
(.049)\end{array}$ & $\begin{array}{l}1.6 \% \\
(.119)\end{array}$ & $\begin{array}{l}1.5 \% \\
(.124)\end{array}$ & $\begin{array}{l}1.7 \% \\
(.117)\end{array}$ & $\begin{array}{l}2.1 \% \\
(.136)\end{array}$ & $\begin{array}{l}2 \% \\
(.152)\end{array}$ \\
\hline Biochemistry & $\begin{array}{l}3.5 \% \\
(.163)\end{array}$ & $\begin{array}{l}3.3 \% \\
(.130)\end{array}$ & $\begin{array}{l}1.5 \% \\
(.153)\end{array}$ & $\begin{array}{l}3.1 \% \\
(.159)\end{array}$ & $\begin{array}{l}4.9 \% \\
(.252)\end{array}$ & $\begin{array}{l}3.5 \% \\
(.187)\end{array}$ & $\begin{array}{l}2.8 \% \\
(.118)\end{array}$ & $\begin{array}{l}1.8 \% \\
(.093)\end{array}$ & $\begin{array}{l}1.4 \% \\
(.105) \\
\end{array}$ \\
\hline $\begin{array}{l}\text { Computer } \\
\text { Science }\end{array}$ & $\begin{array}{l}6.3 \% \\
(.248)\end{array}$ & $\begin{array}{l}5.6 \% \\
(.224)\end{array}$ & $\begin{array}{l}5.8 \% \\
(.225)\end{array}$ & $\begin{array}{l}5.2 \% \\
(.166)\end{array}$ & $\begin{array}{l}5.2 \% \\
(.185)\end{array}$ & $\begin{array}{l}5.8 \% \\
(.148)\end{array}$ & $\begin{array}{l}5 \% \\
(.061)\end{array}$ & $\begin{array}{l}4.2 \% \\
(.072)\end{array}$ & $\begin{array}{l}3.3 \% \\
(.036)\end{array}$ \\
\hline $\begin{array}{l}\text { Environmental } \\
\text { Science }\end{array}$ & $\begin{array}{l}6.3 \% \\
(.176) \\
\end{array}$ & $\begin{array}{l}4.2 \% \\
(.141) \\
\end{array}$ & $\begin{array}{l}4.5 \% \\
(.137) \\
\end{array}$ & $\begin{array}{l}4.8 \% \\
(.146) \\
\end{array}$ & $\begin{array}{l}3.9 \% \\
(.167) \\
\end{array}$ & $\begin{array}{l}2.3 \% \\
(.082) \\
\end{array}$ & $\begin{array}{l}1.6 \% \\
(.099) \\
\end{array}$ & $\begin{array}{l}2.4 \% \\
(.134) \\
\end{array}$ & $\begin{array}{l}1.3 \% \\
(.081) \\
\end{array}$ \\
\hline $\begin{array}{l}\text { General } \\
\text { Medicine }\end{array}$ & $\begin{array}{l}9.7 \% \\
(.296)\end{array}$ & $\begin{array}{l}8.7 \% \\
(.293)\end{array}$ & $\begin{array}{l}7.5 \% \\
(.272)\end{array}$ & $\begin{array}{l}6.8 \% \\
(.241)\end{array}$ & $\begin{array}{l}7 \% \\
(.228)\end{array}$ & $\begin{array}{l}5.2 \% \\
(.167)\end{array}$ & $\begin{array}{l}5.8 \% \\
(.245)\end{array}$ & $\begin{array}{l}4.1 \% \\
(.218)\end{array}$ & $\begin{array}{l}2.9 \% \\
(.177)\end{array}$ \\
\hline Nursing & $\begin{array}{l}11.4 \% \\
(.273)\end{array}$ & $\begin{array}{l}9.9 \% \\
(.262)\end{array}$ & $\begin{array}{l}10.2 \% \\
(.264)\end{array}$ & $\begin{array}{l}9.4 \% \\
(.269) \\
\end{array}$ & $\begin{array}{l}8.4 \% \\
(.208)\end{array}$ & $\begin{array}{l}6.4 \% \\
(.145) \\
\end{array}$ & $\begin{array}{l}5.4 \% \\
(.152) \\
\end{array}$ & $\begin{array}{l}2.8 \% \\
(.098)\end{array}$ & $\begin{array}{l}2.2 \% \\
(.117) \\
\end{array}$ \\
\hline Surgery & $\begin{array}{l}7 \% \\
(.222) \\
\end{array}$ & $\begin{array}{l}6 \% \\
(.198)\end{array}$ & $\begin{array}{l}5.2 \% \\
(.221) \\
\end{array}$ & $\begin{array}{l}3.9 \% \\
(.147) \\
\end{array}$ & $\begin{array}{l}4.3 \% \\
(.169) \\
\end{array}$ & $\begin{array}{l}2.7 \% \\
(.144)\end{array}$ & $\begin{array}{l}2.4 \% \\
(.124) \\
\end{array}$ & $\begin{array}{l}1.7 \% \\
(.038) \\
\end{array}$ & $\begin{array}{l}1.3 \% \\
(.077)\end{array}$ \\
\hline Bus & $\begin{array}{l}15.6 \% \\
(.379) \\
\end{array}$ & $\begin{array}{l}14.9 \% \\
(.371) \\
\end{array}$ & $\begin{array}{l}13.3 \% \\
(.332) \\
\end{array}$ & & & $\begin{array}{l}10 \% \\
(.302) \\
\end{array}$ & $\begin{array}{l}8.2 \% \\
(.195) \\
\end{array}$ & $\begin{array}{l}7.2 \% \\
(.171) \\
\end{array}$ & $\begin{array}{l}4.6 \% \\
(.081)\end{array}$ \\
\hline Education & $\begin{array}{l}13.7 \% \\
(.357)\end{array}$ & $\begin{array}{l}13 \% \\
(.303)\end{array}$ & $\begin{array}{l}13.5 \% \\
(.304)\end{array}$ & $\begin{array}{l}13.5 \% \\
(.297)\end{array}$ & $\begin{array}{l}10 \% \\
(.229)\end{array}$ & $\begin{array}{l}8.6 \% \\
(.235)\end{array}$ & $\begin{array}{l}7.9 \% \\
(.184)\end{array}$ & $\begin{array}{l}6 \% \\
(.145)\end{array}$ & $\begin{array}{l}3.4 \% \\
(.126)\end{array}$ \\
\hline $\begin{array}{ll}\text { Library and } \\
\text { Information Sci. }\end{array}$ & $\begin{array}{l}16.8 \% \\
(.344) \\
\end{array}$ & $\begin{array}{l}16.5 \% \\
(.375) \\
\end{array}$ & $\begin{array}{l}14.4 \% \\
(.297) \\
\end{array}$ & $\begin{array}{l}15.5 \% \\
(.331) \\
\end{array}$ & $\begin{array}{l}14.5 \% \\
(.301) \\
\end{array}$ & $\begin{array}{l}14.4 \% \\
(.270) \\
\end{array}$ & $\begin{array}{l}13.9 \% \\
(.201) \\
\end{array}$ & $\begin{array}{l}11.7 \% \\
(.228) \\
\end{array}$ & $\begin{array}{l}9.6 \% \\
(.188)\end{array}$ \\
\hline Science & $\begin{array}{l}6.8 \% \\
(.194) \\
\end{array}$ & $\begin{array}{l}7.5 \% \\
(.241) \\
\end{array}$ & $\begin{array}{l}6.5 \% \\
(.163) \\
\end{array}$ & $\begin{array}{l}6.1 \% \\
(.203) \\
\end{array}$ & $\begin{array}{l}5.1 \% \\
(.160) \\
\end{array}$ & $\begin{array}{l}4.4 \% \\
(.133) \\
\end{array}$ & $\begin{array}{l}4.2 \% \\
(.125) \\
\end{array}$ & $\begin{array}{l}3.4 \% \\
(.147) \\
\end{array}$ & $\begin{array}{l}3.5 \% \\
(.068) \\
\end{array}$ \\
\hline Psy & $\begin{array}{l}10 \% \\
(.263) \\
\end{array}$ & $\begin{array}{l}8.6 \% \\
(.228) \\
\end{array}$ & $\begin{array}{l}7.5 \% \\
(.203) \\
\end{array}$ & $\begin{array}{l}7.9 \% \\
(.171) \\
\end{array}$ & $\begin{array}{l}6.5 \% \\
(.190) \\
\end{array}$ & $\begin{array}{l}5.7 \% \\
(.197) \\
\end{array}$ & $\begin{array}{l}4 \% \\
(.126) \\
\end{array}$ & $\begin{array}{l}3 \% \\
(.107) \\
\end{array}$ & $\begin{array}{l}2.5 \% \\
(.105)\end{array}$ \\
\hline History & $\begin{array}{l}1.7 \% \\
(.129)\end{array}$ & $\begin{array}{l}1.9 \% \\
(.110)\end{array}$ & $\begin{array}{l}1.9 \% \\
(.094)\end{array}$ & $\begin{array}{l}1.4 \% \\
(.082)\end{array}$ & $\begin{array}{l}1.6 \% \\
(.110)\end{array}$ & $\begin{array}{l}1.2 \% \\
(.073)\end{array}$ & $\begin{array}{l}1.4 \% \\
(.057)\end{array}$ & $\begin{array}{l}0.9 \% \\
(.123)\end{array}$ & $\begin{array}{l}0.9 \% \\
(.066)\end{array}$ \\
\hline Law & $\begin{array}{l}5.9 \% \\
(.194)\end{array}$ & $\begin{array}{l}6.3 \% \\
(.223)\end{array}$ & $\begin{array}{l}6.5 \% \\
(.231)\end{array}$ & $\begin{array}{l}5.6 \% \\
(.205)\end{array}$ & $\begin{array}{l}5.9 \% \\
(.198)\end{array}$ & $\begin{array}{l}5.4 \% \\
(.187)\end{array}$ & $\begin{array}{l}4.4 \% \\
(.177)\end{array}$ & $\begin{array}{l}4 \% \\
(.148)\end{array}$ & $\begin{array}{l}3.1 \% \\
(.167)\end{array}$ \\
\hline Literature & $\begin{array}{l}1.1 \% \\
(.083)\end{array}$ & $\begin{array}{l}1.1 \% \\
(.091)\end{array}$ & $\begin{array}{l}0.7 \% \\
(.059)\end{array}$ & $\begin{array}{l}0.9 \% \\
(.040)\end{array}$ & $\begin{array}{l}1.1 \% \\
(.098)\end{array}$ & $\begin{array}{l}0.7 \% \\
(.057)\end{array}$ & $\begin{array}{l}0.7 \% \\
(.068)\end{array}$ & $\begin{array}{l}0.6 \% \\
(.075)\end{array}$ & $\begin{array}{l}0.6 \% \\
(.063)\end{array}$ \\
\hline Philosophy & $\begin{array}{l}2.1 \% \\
(.129) \\
\end{array}$ & $\begin{array}{l}1.7 \% \\
(.076) \\
\end{array}$ & $\begin{array}{l}2.3 \% \\
(.128) \\
\end{array}$ & $\begin{array}{l}2 \% \\
(.099) \\
\end{array}$ & $\begin{array}{l}2.3 \% \\
(.121) \\
\end{array}$ & $\begin{array}{l}2.4 \% \\
(.070) \\
\end{array}$ & $\begin{array}{l}1.7 \% \\
(.059) \\
\end{array}$ & $\begin{array}{l}1.4 \% \\
(.083) \\
\end{array}$ & $\begin{array}{l}1 \% \\
(.081)\end{array}$ \\
\hline All fields & $\begin{array}{l}7.2 \% \\
(.240)\end{array}$ & $\begin{array}{l}6.9 \% \\
(.228)\end{array}$ & $\begin{array}{l}6.5 \% \\
(.207)\end{array}$ & $\begin{array}{l}6.3 \% \\
(.197)\end{array}$ & $\begin{array}{l}6 \% \\
(.191)\end{array}$ & $\begin{array}{l}5.1 \% \\
(.163)\end{array}$ & $\begin{array}{l}4.5 \% \\
(.138)\end{array}$ & $\begin{array}{l}3.6 \% \\
(.128)\end{array}$ & $\begin{array}{l}2.8 \% \\
(.105)\end{array}$ \\
\hline
\end{tabular}

*Bold figures: Correlations significant at the $p=0.01$ level. Italic figures: Correlations significant at the $p=0.05$ level.

\section{RQ5: Which types of SlideShare document are cited by academic papers?}

Of the 480 SlideShare URLs sampled from the cited references of Scopus publications for the content analysis, 14 were not accessible at the time of study and the remainder were examined $(480-14=466)$. Just over a third ( $35 \%$ or 165 out of 466$)$ of the Scopus citations to 
SlideShare were to presentations but most (64\%) were to publications rather than presentations. These publications included uploaded preprints/postprints of articles and book chapters. In Astronomy and Astrophysics, nearly all of the Scopus citations were to publications (articles 29 out of 30) whereas in Library and Information Science only a third (11 out of 30) were.

Just under two-thirds (63\%) of the cited SlideShare documents that were classified as presentations were research-related - either conference $(27 \%)$ or other research presentations (37\%) (Table 6). A substantial minority (21\%) were created for some type of teaching, mostly within academia (18\%). The remaining $15 \%$ had no clear indication of research or teaching relevance. For example, the presentation "Gamers nights WAGE 2014 presentation" described a multiplayer gaming community in Uganda and gave infrastructure performance details that might be of interest within computer science research.

Most (56\%) authors of SlideShare presentations cited by Scopus articles were academics and the remainder were mainly created by health, business or other professionals. Some of the presentations were corporate, crediting the owning business or other organisation rather than an individual (Table 7). Nevertheless, since nearly half of the cited SlideShare presentations are apparently of non-academic origin, SlideShare seems to be a conduit through which non-academic information can be accessed by academics for research purposes.

Table 6. SlideShare documents cited by Scopus articles and classified as presentations, categorised by research or teaching orientation (derived from data set 3: Scopus articles citing SlideShare presentations; $n=165$ ). Figures reported are the averages of the two coders.

\begin{tabular}{|l|r|}
\hline Research or teaching orientation & Number of presentations \\
\hline Conference presentation & $44.5(27 \%)$ \\
\hline Other research presentation & $60.5(37 \%)$ \\
\hline Academic teaching presentation & $29.5(18 \%)$ \\
\hline Other teaching presentation & $5(3 \%)$ \\
\hline Other presentation & $25.5(15 \%)$ \\
\hline
\end{tabular}

Table 7. SlideShare documents cited by Scopus articles and classified as presentations, categorised by author or creator type (derived from data set 3: Scopus articles citing SlideShare presentations; $n=165$ ). Figures reported are the averages of the two coders.

\begin{tabular}{|l|r|}
\hline Author or creator & Number of presentations \\
\hline Academics & $92.5(56 \%)$ \\
\hline Health professionals & $17(10 \%)$ \\
\hline Business managers, directors and consultants (individuals) & $11.5(7 \%)$ \\
\hline Non-profit organisations & $10(6 \%)$ \\
\hline Companies (businesses credited as slide authors) & $6(4 \%)$ \\
\hline Other professionals & $12(7 \%)$ \\
\hline Others or unknown & $10(6 \%)$ \\
\hline Not mentioned & $6(4 \%)$ \\
\hline
\end{tabular}

The slides attracting the most citations (Table 8 ) were typically not by academics (with two exceptions) but were from consultants or business employees. Although some were 
particularly attractive, most gave detailed information that could be useful to cite in research about the topic of the report. Most of the slides gave information that would not be put in the academic domain. The main topics were the social web and the internet, although computing more generally may also be a theme. Two were business reports rather than any type of presentation. Presumably these were posted online but the authors had given related presentations, perhaps without slides. 
Table 8. SlideShare documents with at least 4 Scopus citations by September 2015 (derived from data set 3: Scopus articles citing SlideShare documents).

\begin{tabular}{|c|c|c|c|}
\hline Title & Author type & Document type and topic & Cites \\
\hline $\begin{array}{l}\text { Opportunities and } \\
\text { barriers in the } \\
\text { biosimilar market }\end{array}$ & $\begin{array}{l}\text { Pharmaceutical strategy } \\
\text { consultants, } \\
\text { PricewaterhouseCoopers } \\
\text { LLP }\end{array}$ & $\begin{array}{l}\text { Paper about biopharmaceutical } \\
\text { markets }\end{array}$ & 6 \\
\hline Social crm & $\begin{array}{l}\text { Assoc. Director, Sales \& } \\
\text { Marketing Innovation } \\
\text { Latin America, Kraft } \\
\text { Foods }\end{array}$ & $\begin{array}{l}\text { High quality slides about } \\
\text { customer relations management }\end{array}$ & 5 \\
\hline $\begin{array}{l}\text { The real life social } \\
\text { network v2 }\end{array}$ & VP of Product, Intercom & $\begin{array}{l}\text { High quality slides and notes } \\
\text { pages about social networks }\end{array}$ & 5 \\
\hline $\begin{array}{l}\text { XBRL world wide } \\
\text { adoption survey }\end{array}$ & $\begin{array}{l}\text { XBRL International } \\
\text { Steering Committee }\end{array}$ & $\begin{array}{l}\text { Detailed slides about the } \\
\text { eXtensible Business Reporting } \\
\text { Language }\end{array}$ & 5 \\
\hline $\begin{array}{l}\text { Putting the fun in } \\
\text { functional }\end{array}$ & $\begin{array}{l}\text { Mentor at Maven } \\
\text { Ventures }\end{array}$ & $\begin{array}{l}\text { High quality slides about making } \\
\text { functional software more fun }\end{array}$ & 4 \\
\hline Plurk analysis & $\begin{array}{l}\text { InRev systems, } \\
\text { Bangalore }\end{array}$ & $\begin{array}{l}\text { Report about the free social } \\
\text { networking and micro-blogging } \\
\text { service Plurk }\end{array}$ & 4 \\
\hline $\begin{array}{l}2012 \text { Edelman trust } \\
\text { barometer }\end{array}$ & Edelman Insights & $\begin{array}{l}\text { Detailed slides about a trust and } \\
\text { credibility survey. }\end{array}$ & 4 \\
\hline $\begin{array}{l}\text { Why the private } \\
\text { sector is key to cyber } \\
\text { defence }\end{array}$ & Cybersecurity consultant & $\begin{array}{l}\text { Detailed slides about } \\
\text { cybersecurity }\end{array}$ & 4 \\
\hline $\begin{array}{l}\text { Social media around } \\
\text { the world } 2012\end{array}$ & InSites Consulting & $\begin{array}{l}\text { High quality, very detailed slides } \\
\text { about social media } \\
\text { internationally }\end{array}$ & 4 \\
\hline Cloud computing 2010 & IDC (company) & $\begin{array}{l}\text { Detailed slides about cloud } \\
\text { computing }\end{array}$ & 4 \\
\hline $\begin{array}{l}\text { KZero universe q4 } \\
2011\end{array}$ & KZero Worldswide & $\begin{array}{l}\text { Detailed slides about the origins } \\
\text { and demographics of virtual } \\
\text { worlds }\end{array}$ & 4 \\
\hline $\begin{array}{l}\text { Mobile learning: } \\
\text { South African } \\
\text { examples }\end{array}$ & $\begin{array}{l}\text { Head of Mobile at } \\
\text { Pearson South Africa }\end{array}$ & $\begin{array}{l}\text { Detailed good slides about } \\
\text { mobile learning }\end{array}$ & 4 \\
\hline $\begin{array}{l}\text { Lean construction - } \\
\text { introduction }\end{array}$ & $\begin{array}{l}\text { Professor, Michigan } \\
\text { State Uni. }\end{array}$ & $\begin{array}{l}\text { Detailed slides (271) about lean } \\
\text { construction }\end{array}$ & 4 \\
\hline $\begin{array}{l}\text { Generación } 2.0 \text { - } \\
\text { hábitos de los } \\
\text { adolescentes }\end{array}$ & $\begin{array}{l}\text { Professors, Universidad } \\
\text { Camilo José Cela }\end{array}$ & $\begin{array}{l}\text { Detailed slides about young } \\
\text { social web users }\end{array}$ & 4 \\
\hline $\begin{array}{l}\text { Social, digital \& } \\
\text { mobile around the } \\
\text { world }\end{array}$ & We Are Social Singapore & $\begin{array}{l}\text { Detailed slides ( } 183 \text { ) with } \\
\text { statistics about social, digital and } \\
\text { mobile channels }\end{array}$ & 4 \\
\hline
\end{tabular}




\section{Discussion}

An important limitation of this study is that the affordances of SlideShare, its popularity and usage patterns may change over time, even though there seemed to be stability in the results between 2010 and 2015. The analyses also take the information available in SlideShare at face value (e.g., view counts, author self-descriptions), whereas some site statistics may be inflated for technical reasons, such as visits by web crawlers, and selfreported information may be deliberately misleading. The data that was gathered from Bing is likely to be an underestimate of the number of webpages matching the search because search engines do not index the entire web (Lawrence \& Giles, 1999) and do not always return all valid query matches for pages that they have crawled (Bar-llan \& Peritz, 2004; for Bing see: Thelwall, 2008).

After taking into account the reduced time for newer documents to be viewed and some documents becoming obsolete or less relevant over time, the time series graphs suggest that the use of SlideShare has been very approximately stable over about a decade. Because of the time, user-base and other factors that affect the popularity of a resource, it is difficult to identify whether the underlying trend is increasing or decreasing. Nevertheless, newer documents do not attract substantially more or fewer views, for example. This is encouraging for both existing and new users.

The results point to SlideShare being a site that is predominantly for professional users rather than academics, teachers or students, even though there is evidence of a substantial minority of academic and educational uses, and some uptake by academics of material posted by other professionals. Professionals may give talks as part of their jobs at meetings, industry conferences and for work-based training. It is natural that some would share their presentations online afterwards, although it is not clear whether Slideshare is usually a site of convenience or whether it represents an attempt to attract a wider audience. It is also not clear whether sites like SlideShare can provide a source of information for academics and others that might need to attend professional conferences (Lyons, 2007) but could now find at least some of the same information online.

SlideShare is unusual from an academic perspective in that its most cited presentations and documents are rarely from reputable scholarly sources, such as senior academics. It may be that academics tend to publish their best work through traditional outlets and that SlideShare gives space for others that have valuable information to impart but do not have the need or skills to convert this information into academic publications. Conversely, senior academics may lack the skills or incentive to publish their presentations in social web sources (Mas-Bleda et al., 2014). Thus, SlideShare may form a particularly useful way in which non-academic sources and types of information can reach a wider audience, sometimes being incorporated into academic research through formal citations.

From the perspective of exploiting SlideShare as a new altmetric source of citation to academic documents (Priem, et al., 2010), the content analysis of a random of 480 SlideShare documents citing Scopus articles found that most of the citing SlideShare documents were academic publications rather than slides, and so citations from SlideShare are unlikely to reflect the wider impacts of research. Citations from SlideShare seem more likely to reflect academic impact, with elements of professional impact from non-academic uploaders, and educational impact for slides created for, or within, education. This is more promising than a similar content analysis of Twitter citations of academic articles, which found that most gave little evidence of real impact (Thelwall, Tsou, Weingart, Holmberg, \& Haustein, 2013), although there may be disciplinary differences (Holmberg \& Thelwall, 
2014). Nevertheless, many publications uploaded to SlideShare are probably also indexed in other citation databases, such as Scopus, WoS and Google Scholar. Moreover, given the relatively small numbers of citations from SlideShare, it does not seem to make sense to use it for academic impact, because Scopus has many more citations and is therefore a much bigger source of similar impact information. Thus, SlideShare does not seem useful from the prospective of providing a new indicator for academic articles and is less promising than methods to systematically search for presentation files online (Thelwall \& Kousha, 2008).

Popularity statistics from SlideShare may be useful for the authoring academics and others to give as evidence of the level of interest shown in their presentations, echoing previous comments about YouTube (Kousha, Thelwall, \& Abdoli, 2012) and Ted Talks (Sugimoto \& Thelwall, 2013). Thus, there are increasingly many ways in which speakers that make a valuable contribution to scholarship primarily through their presentations and talks can use online popularity statistics as evidence of the impact of their work.

In order to get more information about academic and educational uses of SlideShare, the Bing API was used to search for the URL "www.slideshare.net/" as a phrase search and combined with a list of over 24,000 university websites from around the world (e.g., "www.slideshare.net/" site:nyu.edu for New York University). This produced a list of 18,466 academic webpages that gave the URL of a SlideShare website page. Hence, on average, SlideShare URLs are mentioned in three quarters of a page per university. Presumably, it is used in universities far more often than its URLs are included in webpages and so this suggests that there is a low but non-trivial level of interest in the site. The results were then filtered to identify documents that were likely to be academic syllabi or course reading lists using previously-tested methods (Kousha \& Thelwall, in press). About $8 \%(1,555)$ were from academic syllabi and course reading lists. Of these, just under half were from U.S. academic institutions (49\%), followed by the U.K. (5\%) and Canada (4\%). This suggests that a small number of academics (at least) are using SlideShare in their teaching. For example, the syllabus for a paleontology course at Indiana University ${ }^{9}$ cited a presentation explaining how to install a specific set of web software needed (Installing and Configuring a WAMP Server in Windows 7 \& 8) written by a professional from Trinidad and Tobago, a University College London academic research methods module for Science and Technology Studies $(\mathrm{STS})^{10}$, listed the SlideShare presentation "8 tips for an awesome powerpoint presentation" by a marketing professional from Barcelona as essential reading for a week about giving presentations, and a psychology research methods module at Glyndwr University in Wales cited a Malaysian academic's SlideShare presentation "Research Methodology Lecture for Master \& PhD Students" as an online resource for students. Thus, it seems that there is space for SlideShare to provide content to aid education, although the same is presumably true for many other sites, such as YouTube and TED Talks.

\section{Conclusions}

This analysis of general SlideShare documents and SlideShare documents cited by, or citing, Scopus articles has shown that the site contains mainly professional users and documents, albeit with a substantial minority of academic and educational content. It does not seem to privilege any particular type of user, in terms of the popularity of their uploaded documents and therefore is particularly recommended as a place to upload, and find, information and

\footnotetext{
${ }^{9}$ http://www.indiana.edu/ g563/G563\%20Syllabus.pdf

${ }^{10}$ https://www.ucl.ac.uk/sts/study/hpsc/2014-15_syllabi/HPSC1007_Syllabus_REV_2014-15
} 
sources that are outside of the mainstream of academia. Those that do so may be able to use the popularity statistics in the site as evidence of their impact, although such data can be manipulated (Wouters \& Costas, 2012). In contrast, the evidence points to citations from SlideShare documents having little value as impact indicators for academic research. SlideShare seems to be stable in terms of the popularity of its resources over time, and so there is no reason to fear that interest in it is declining, its usage is changing, or that these conclusions will be invalid in the near future.

Perhaps the most useful conclusion is that SlideShare has become a repository of a vast number of non-academic presentations and other documents. Like the web itself and other sites, including Wikipedia, it may therefore provide specialist information and knowledge that was previously difficult to find or remained unpublished. It may be particularly useful within education and training, given that most SlideShare documents take the form of a presentation even though some are other types of document.

In terms of future research, it would be interesting to find more out about the professional uploaders, and particularly those that have produced successful presentations. It may be, for example, that they are eminent in their areas or that they are unrecognised experts for which SlideShare provided a skills outlet. It would also be helpful to investigate the type of content uploaded to SlideShare in more depth. The evidence presented above suggests that the main domains of interest are business, library and information science, education and perhaps also computing. Within these, generic soft skills such as research methods and presenting may be particularly useful to academia. Finally, given that SlideShare presentations are non-refereed but used in education, academic research and, presumably, business, it would be useful to assess the quality of the information presented in popular presentations in order to check whether there is any cause for concern.

\section{References}

Archambault, É., Campbell, D., Gingras, Y., \& Larivière, V. (2009). Comparing bibliometric statistics obtained from the Web of Science and Scopus. Journal of the American Society for Information Science and Technology, 60(7), 1320-1326.

Bar-Ilan, J., \& Peritz, B. C. (2004). Evolution, continuity, and disappearance of documents on a specific topic on the Web: A longitudinal study of 'informetrics'. Journal of the American Society for Information Science and Technology, 55(11), 980 - 990.

Cherrstrom, C. A. (2012). Making connections: Attending professional conferences. Adult Learning, 23(3), 148-152.

Cohen, J. (1960). A coefficient of agreement for nominal scales. Educational and Psychological Measurement, 20(1), 37-46.

de Moya-Anegón, F., Chinchilla-Rodríguez, Z., Vargas-Quesada, B., Corera-Álvarez, E., Muñoz-Fernández, F., González-Molina, A., \& Herrero-Solana, V. (2007). Coverage analysis of Scopus: A journal metric approach. Scientometrics, 73(1), 53-78.

Egri, C. P. (1992). Academic conferences as ceremonials: Opportunities for organizational integration and socialization. Journal of Management Education, 16(1), 90-115.

Eveillard, P. (2013). Social networks in 10 lessons: No3. Entrust your presentations with SlideShare! Revue du Praticien, 63(3), 384.

Gerido, L., \& Curran, M. C. (2014). Enhancing science instruction through student-created PowerPoint presentations. The American Biology Teacher, 76(9), 627-631.

Haran, B., \& Poliakoff, M. (2011). The periodic table of videos. Science, 332(6033), 10461047. 
HEFCE (2015). The Metric Tide: Correlation analysis of REF2014 scores and metrics (Supplementary Report II to the Independent Review of the Role of Metrics in Research Assessment and Management). HEFCE. DOI: 10.13140/RG.2.1.3362.4162

Holliman, R., \& Jensen, E. (2009). (In)authentic science and (im)partial publics: (Re)constructing the science outreach and public engagement agenda. In: Holliman, R., Whitelegg, L., Scanlon, E., Smidt, S., \& Thomas, J. (eds) Investigating science communication in the information age: Implications for public engagement and popular media. Oxford: Oxford University Press (pp. 35-52).

Holmberg, K. \& Thelwall, M. (2014). Disciplinary differences in Twitter scholarly communication, Scientometrics, 101(2), 1027-1042.

Johnson, S.B. (2015). On-line pesticide training with narrated PowerPoint presentations. Journal of Extension, 53(3), http://www.joe.org/joe/2015june/tt8.php

Jon (2007). New features- file download and creating groups..., Slideshare Blog, https://blog.slideshare.net/2007/04/16/new-features-file-download-and-creatinggroups/

Kousha, K., Thelwall, \& Abdoli, M. (2012). The role of online videos in research communication: A content analysis of YouTube videos cited in academic publications. Journal of the American Society for Information Science and Technology, 63(9), 17101727.

Kousha, K. \& Thelwall, M. (2015). Web indicators for research evaluation, part 3: Books and non-standard outputs. El Profesional de la Información, 24(6), 724-736. doi:10.3145/epi.2015.nov.04

Kousha, K. \& Thelwall, M. (in press). An automatic method for assessing the teaching impact of books from online academic syllabi. Journal of the Association for Information Science and Technology. doi:10.1002/asi.23542

Kung, Y. M., \& Oh, S. (2014). Characteristics of nurses who use social media. Computers Informatics Nursing, 32(2), 64-72.

Landis, J. R., \& Koch, G. G. (1977). The measurement of observer agreement for categorical data. Biometrics, 33(1), 159-174.

Lawrence, S., \& Giles, C. L. (1999). Accessibility of information on the web. Nature, 400(6740), 107-107.

Lisée, C., Larivière, V., \& Archambault, É. (2008). Conference proceedings as a source of scientific information: A bibliometric analysis. Journal of the American Society for Information Science and Technology, 59(11), 1779-1784.

Loof, J. (2013). A new way to discover and share SlideShares! SlideShare Blog, https://blog.slideshare.net/2013/09/05/a-new-way-to-discover-and-shareslideshares/

López-Illescas, C., de Moya-Anegón, F., \& Moed, H. F. (2008). Coverage and citation impact of oncological journals in the Web of Science and Scopus. Journal of Informetrics, 2(4), 304-316.

Lyons, L. E. (2007). The dilemma for academic librarians with collection development responsibilities: A comparison of the value of attending library conferences versus academic conferences. The Journal of Academic Librarianship, 33(2), 180-189.

Mas-Bleda, A., Thelwall, M., Kousha, K. \& Aguillo, I.F. (2014). Do highly cited researchers successfully use the Social Web? Scientometrics, 101(1), 337-356.

Merton, R. K. (1973). The sociology of science: Theoretical and empirical investigations. Chicago, IL: University of Chicago press. 
Moed, H. F. (2006). Citation analysis in research evaluation. Berlin: Springer.

Narin, F., \& Noma, E. (1985). Is technology becoming science? Scientometrics, 7(3-6), 369381.

Oppermann, M. (1997). Tourism conferences - academic titillation, social interactions or job market? Tourism Management, 18(5), 255-257.

Petticrew, M., Egan, M., Thomson, H., Hamilton, V., Kunkler, R., \& Roberts, H. (2008). Publication bias in qualitative research: What becomes of qualitative research presented at conferences? Journal of Epidemiology and Community Health, 62(6), 552-554.

Priem, J., Taraborelli, D., Groth, P., \& Neylon, C. (2010). Altmetrics: A manifesto. http://altmetrics.org/manifesto/

Scherer, R. W., Dickersin, K., \& Langenberg, P. (1994). Full publication of results initially presented in abstracts: A meta-analysis. JAMA: The Journal of the American Medical Association, 272(2), 158-162.

Schoeneborn, D. (2015). The pervasive power of PowerPoint: How a genre of professional communication permeates organizational communication. Organization Studies, 34(12), 1777-1801.

Seeborg, K. (2013). SlideShare and Linkedln sitting in a tree... SlideShare Blog, http://blog.slideshare.net/2012/05/03/linkedin-acquires-slideshare/

Shalom, C. (1993). Established and evolving spoken research process genres: Plenary lecture and poster session discussions at academic conferences. English for Specific Purposes, 12(1), 37-50.

Sud, P. \& Thelwall, M. (2014). Evaluating altmetrics. Scientometrics, 98(2), 1131-1143. 10.1007/s11192-013-1117-2.

Sugimoto, C.R. \& Thelwall, M. (2013). Scholars on soap boxes: Science communication and dissemination via TED videos. Journal of the American Society for Information Science and Technology, 64(4), 663-674.

Sugimoto, C.R., Thelwall, M., Larivière, V., Tsou, A., Mongeon, P., Macaluso, B. (2013). Scientists popularizing science: Characteristics and impact of TED Talk presenters. PLoS ONE, 8(4), e62403. doi:10.1371/journal.pone.0062403

Thelwall, M. \& Kousha, K. (2008). Online presentations as a source of scientific impact? An analysis of PowerPoint files citing academic journals. Journal of the American Society for Information Science and Technology, 59(5), 805-815.

Thelwall, M., \& Kousha, K. (2015a). Web indicators for research evaluation, part 1: Citations and links to academic articles from the web. El Profesional de la Información, 24(5), 587-606. doi:10.3145/epi.2015.sep.08

Thelwall, M., \& Kousha, K. (2015b). Web indicators for research evaluation, part 2: Social media metrics. El Profesional de la Información, 24(5), 607-620. doi:10.3145/epi.2015.sep.09

Thelwall, M. Tsou, A., Weingart, S., Holmberg, K., \& Haustein, S. (2013). Tweeting links to

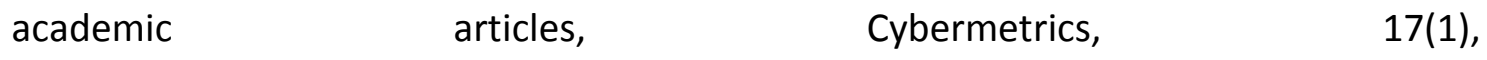
http://cybermetrics.cindoc.csic.es/articles/v17i1p1.html

Thelwall, M. \& Sud, P. (2012). Webometric research with the Bing Search API 2.0. Journal of Informetrics, 6(1), 44-52.

Thelwall, M. (2008). Quantitative comparisons of search engine results, Journal of the American Society for Information Science and Technology, 59(11), 1702-1710. 
Thelwall, M. (2014). Five recommendations for using alternative metrics in the future UK Research Excellence Framework. http://blogs.Ise.ac.uk/impactofsocialsciences/2014/10/23/alternative-metrics-futureuk-research-excellence-framework-thelwall/

Tomaszewski, R., \& MacDonald, K. I. (2009). Identifying subject-specific conferences as professional development opportunities for the academic librarian. The Journal of Academic Librarianship, 35(6), 583-590.

Torres-Salinas, D., \& Milanés-Guisado, Y. (2014). Presencia en redes sociales y altmétricas de los principales autores de la revista" El Profesional de la Información". El Profesional de la Información, 23(4), 367-372.

van Raan, A. F. (1998). In matters of quantitative studies of science the fault of theorists is offering too little and asking too much. Scientometrics, 43(1), 129-139.

Weale, A. R., Edwards, A. G., Lear, P. A., \& Morgan, J. D. T. (2006). From meeting presentation to peer-review publication - A UK review. Annals of the Royal College of Surgeons of England, 88(1), 52-56.

Wouters, P., \& Costas, R. (2012). Users, narcissism and control: tracking the impact of scholarly publications in the 21st century (pp. 847-857). Utrecht: SURFfoundation.

Xia, J. (2008). A comparison of subject and institutional repositories in self-archiving practices. The Journal of Academic Librarianship, 34(6), 489-495.

Zuccala, A. \& van Leeuwen, T. (2011). Book reviews in humanities research evaluations. Journal of the American Society for Information Science and Technology, 62(10), 19791991. 